\title{
Fe(III)-Catalyzed Enantioselective Conia-ene Reaction
}<smiles>[R]C(CN=CC#C)C(=O)O</smiles><smiles>C=C1CCCC1C=O</smiles>

up to $97 \%$ yield up to $98 \%$ ee

\section{Selected examples:}

5-membered rings<smiles>C=C1CCCC1(C(=O)OCC)C(=O)c1ccccc1</smiles><smiles>C=C1CCCC1(C(C)=O)C(C)=O</smiles>

$93 \%$ yield
$93 \%$ ee<smiles>C=C1CCC[C@]1(C(=O)C1CC1)C(=O)[N+](=O)[O-]</smiles>

$98 \%$ yield $96 \%$ ee

4-, 6-, and 7-membered rings

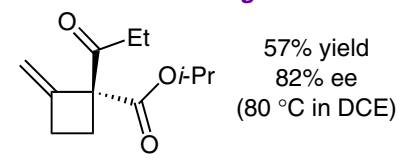

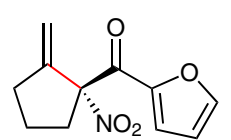

$91 \%$ yield $92 \%$ ee

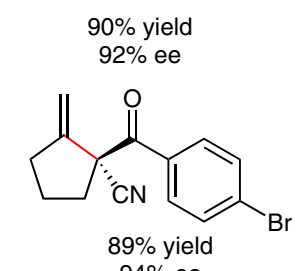
$94 \%$ ee

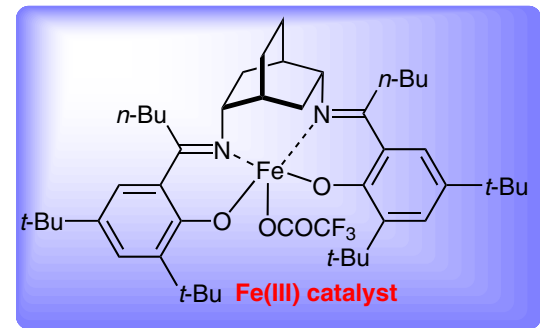<smiles>C=C1CCCC1(C(C)=O)C(C)=O</smiles>

Category

Metal-Catalyzed Asymmetric

Synthesis and

Stereoselective

Reactions

\section{Key words}

\section{iron}

salen ligands

Conia-ene reaction

carbocyclization
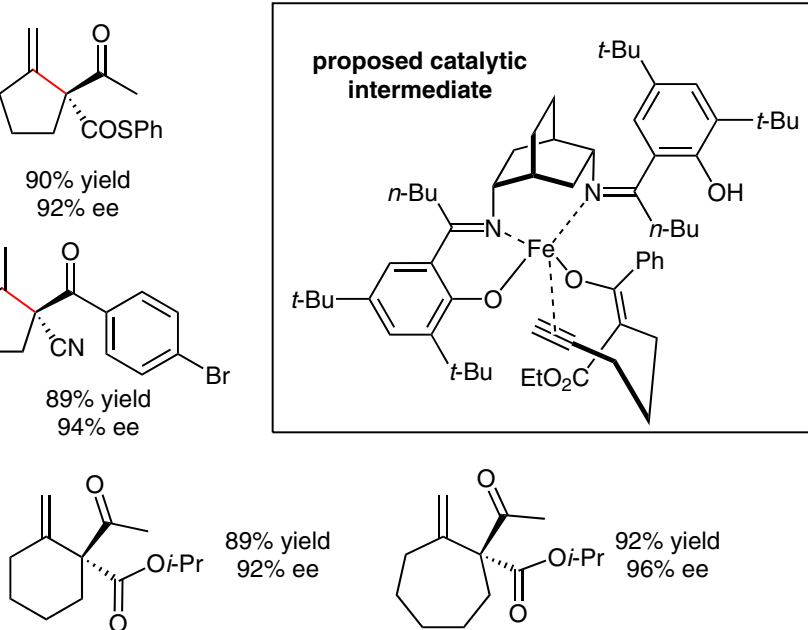

Significance: The Conia-ene reaction represents a powerful approach to form chiral all-carbon quaternary centers (see Review below). Current methods for the enantioselective Conia-ene reaction commonly employ a dual catalytic system comprised of a hard and a soft Lewis acid (selected references: B. K. Corkey, F. D. Toste J. Am. Chem. Soc. 2005, 127, 17168; T. Yang et al. J. Am. Chem. Soc. 2009, 131, 9140; A. Matsuzawa et al. Angew. Chem. Int. Ed. 2011, 50, 7616). White and co-workers now report that a single $\mathrm{Fe}(\mathrm{III})$-salen catalyst can efficiently promote the enantioselective Conia-ene reaction with high enantioselectivities.

Review: F. Dénès et al. Chem. Rev. 2010, 110, 2366-2447.

SYNFACTS Contributors: Mark Lautens, Christine M. Le Synfacts 2014, 10(12), 1273 Published online: 18.11.2014 Dol: 10.1055/s-0034-1379531; Reg-No.: L14214SF
Comment: The method developed by White and co-workers provides access to the desired carbocycles in generally very high yields (>90\%) and enantioselectivities (>90\%). In addition to the formation of 5-membered rings, larger $(6,7)$ and smaller (4) rings can also be formed - albeit in lower yields and enantioselectivities in the latter case. The authors propose that the Fe(III) catalyst serves to simultaneously activate the alkyne towards nucleophilic attack, as well as form the key metal enolate species. 